異なる経過をたどったChronic Expanding Hematoma の 3 手術例

宮内 善広，奥脇 英人，松原 寛知

松岡 弘泰, 内田嚴, 松本 雅彦

\begin{abstract}
要 旨
【はじめに】異なる経過をたどった Chronic Expanding Hematoma（CEH）の 3 手術例を報告する.【症例 1】胸腹部大動脈 瘤術後の 70 歳, 男性. 創部皮下に有痛性の腫瘤を自覚し受診. 可及的血腫除去を行うも, 膿胸となりドレーンを留置して退 院. 術後 1 年経過時に脳出血で死亡した. 【症例 2 】結核にて左肺上葉切除既往のある 74 歳, 女性. 発熱と血痰が出現し受診. 左胸膜肺摘除を施行し, 術後 2 年経過し独歩通院中である. 【症例 3】 右結核性胸膜炎の既往のある 74 歳, 男性. 拡大傾向の ある胸腔内腫瘤に対し, 右肺下葉切除を伴う血腫/被膜除去を施行. 術後 1 年経過し独歩通院中である. 【考察】CEH は持続的 に増大する血腫であり，様々な臨床経過をとりうる，治療としては被膜の完全切除を伴う血腫除去が望ましいが，高侵襲手 術となることも多く各症例の全身状態に応じた治療戦略が必要である.
\end{abstract}

索引用語：慢性出血性膿胸, 肺結核症, 胸膜肺摘除

chronic expanding hematoma, pulmonary tuberculosis, pleuro-pneumonectomy

\section{はじめに}

Chronic Expanding Hematoma（以 下 CEH）は 1980 年に Reid らが提唱した疾患概念で, 外傷などの最初の出 血から 1 力月以上経過してから持続性に増大する血腫 ${ }^{1)}$ とされ，呼吸器外科領域では慢性膿胸の特殊型として慢 性出血性膿胸”2どと呼称されている.今回当科で経験し た 3 手術例を報告する。

\section{症例}

症例 $1: 70$ 歳, 男性.

主 訴：左季肋部の有痛性腫瘤.

現病歴：64歳時に胸腹部大動脈瘤に対し左開胸開腹 にて人工血管置換術後, 慢性腎不全および特発性血小板 減少症にて通院中であった，術後 5 年経過時より, 術創 部近傍に腫瘤を認めた．穿刺にて血液のみが引けるため 経過観察とされていたが, 徐々に拡大し疼痛を伴うょう

山梨大学第二外科

原稿受付 2012年 7 月 16 日

原稿採択２012年 9 月27日
になってきたため, 治療目的に入院となった.

入院時現症 : 左季肋部, 創部近傍に小手拳大の有痛性 腫瘤を認めたが感染兆候はなかった．Performance Statusは 2 であった。

血液検査所見：血清クレアチニン值は $2.31 \mathrm{mg} / \mathrm{dl}$. 血 小板は $8000 / \mathrm{mm}^{3}$ と低下していた. 貧血はなく, 凝固系そ の他に異常はなかった。

胸部単純 $\mathbf{X}$ 線所見 : 左下肺野の透過性低下を認めた (Fig. 1).

胸部 CT 所見：左横隔膜上 8 9 肋間を中心に内部に 石灰化を伴い，分葉状で胸壁外へ伸展する最大径 $13 \mathrm{~cm}$ 大の不整形腫瘤を認めた (Fig. 2).

手術所見：全身状態から高侵襲な血腫被膜完全切除は 困難と考え，全身麻酔下に腫瘤直上を切開して可及的に 胸腔内外の血腫除去を行い, ドレーンを留置し終了した。

術後経過：術後 15 日頃に緑膿菌による無瘻性膿胸を 発症したため, 全身麻酔下に洗浄ドレーン再留置を行い, 洗浄を継続し術後 4 カ月で退院した．外来にてドレーン の処置を継続していたが, 術後 1 年経過時に脳出血を発 症し死亡した。

症例 $2: 74$ 歳, 女性. 


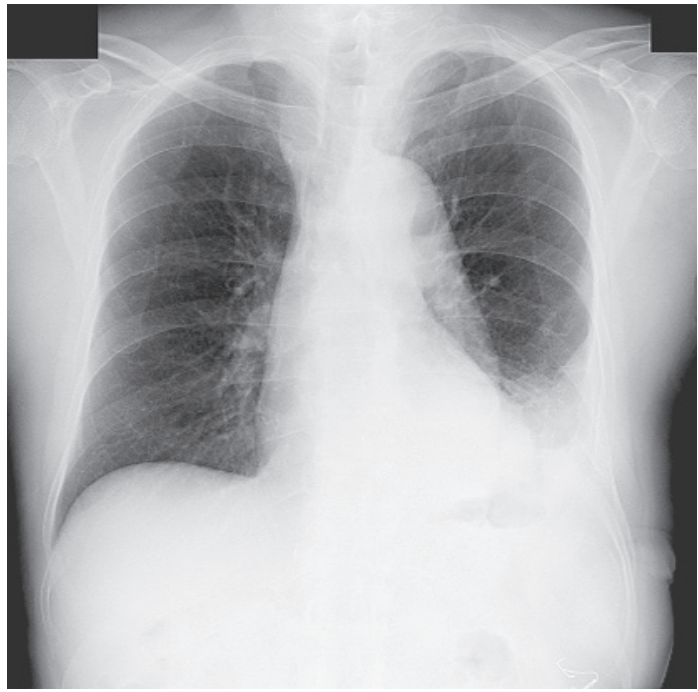

Fig. 1 Chest radiograph showing a mass in the left lower lung field.

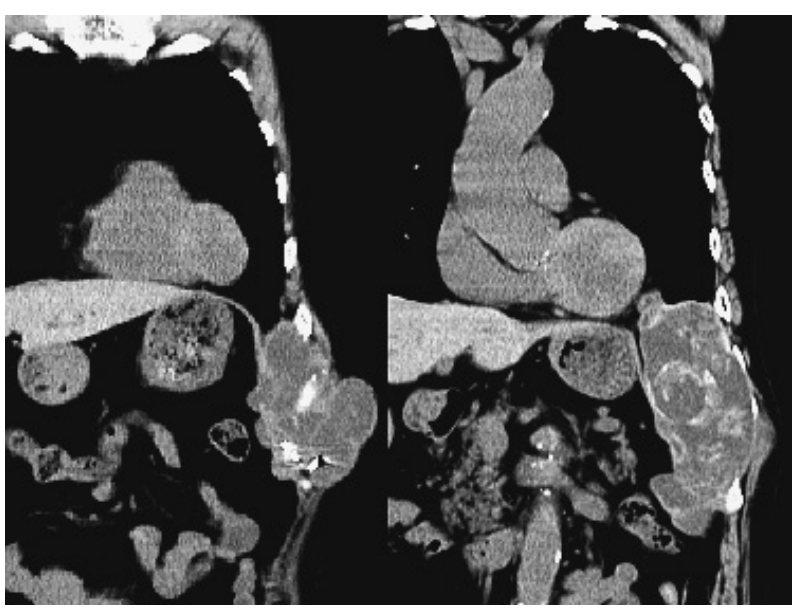

Fig. 2 Chest CT scan showing the mass, $13 \mathrm{~cm}$ in size, with calcification. The mass protruded beyond the lateral chest wall.

主 訴：血痰，胸部圧迫感，発熱，左腋窩腫瘤.

既往歴：20 歳頃に肺結核に対し左肺上葉切除施行. 50 歳頃から慢性 C 型肝炎にて経過観察中。

現病歴：70歳頃から左慢性膿胸として経過観察され てきたが，徐々に胸部圧迫感が出現した。ささらに血痰の 増加と発熱が続き, 左腋窩の急激な腫瘤増大を認めたた め穿刺施行され，血腫の診断で加療目的に当科に紹介と なった。

入院時現症 : 体温 $37.6^{\circ} \mathrm{C}$, 左後側方切開痏痕を認め, 左 腋窩〜胸部側方に膨隆/硬結を認めた。

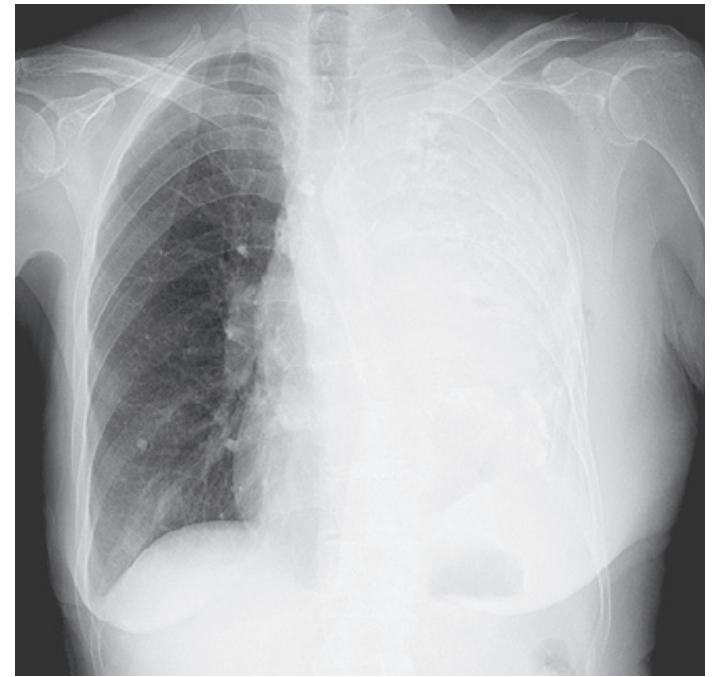

Fig. 3 Chest radiograph showing total opacity of the left hemithorax.

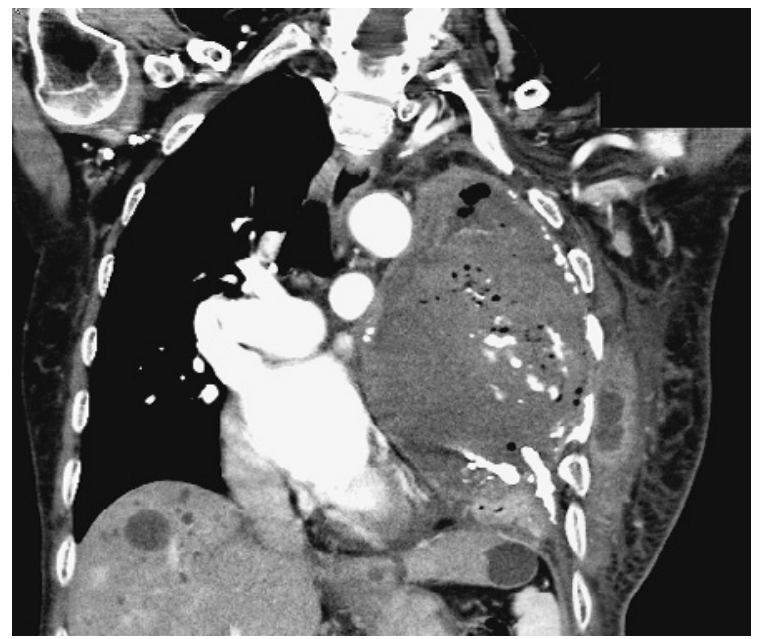

Fig. 4 Chest CT scan showing the huge mass, $17 \mathrm{~cm}$ in size, with calcification protruding beyond the lateral chest wall, and left lower lung lobe atelectasis caused by the mass.

血液検查所見 : $\mathrm{CRP}$ は $5.03 \mathrm{mg} / \mathrm{dl}$ と上昇,へモグロビ ンは $9.0 \mathrm{~g} / \mathrm{dl}$ と低下していた．その他に大きな異常はな かった.

胸部単純 $X$ 線所見：左全肺野の含気を認めなかった (Fig. 3).

胸部 CT 所見：左胸腔内を占拠する最大径 $17 \mathrm{~cm}$ 大 で，内部に石灰化を伴う腫瘤が胸壁外へ伸展し，左残存 肺は無気肺を呈し，縦隔は右に偏位していた（Fig.4）. 手術所見：左後側方切開により胸壁内外の血腫被膜切 
除および左胸膜肺摘除術を施行. 心膜, 腹膜とも開放せ ずに剥離可能であった，左閉塞性肺炎を併発していたた め, 横隔膜は人工物による再建を避けて温存した筋層を 縫縮して再建した.

術後経過：1 病日に再開胸止血を要したが，46病日に 独歩退院. 感染やその他呼吸器合併症の兆候はなく, 術 後 2 年経過し独歩通院中である.

症例 $3: 74$ 歳, 男性.

主 訴：特になし。

既往歴：10歳代に結核性胸膜炎に対し治療歴があっ

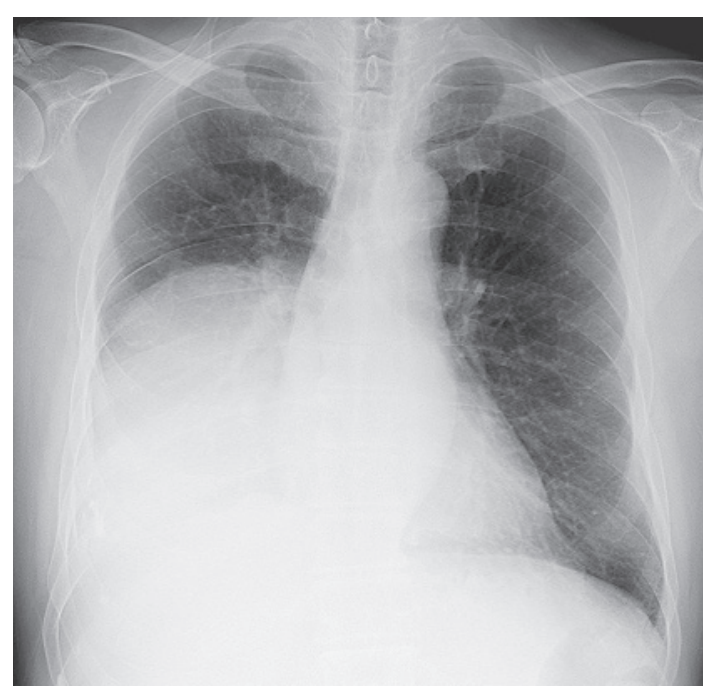

Fig. 5 Chest radiograph showing a mass in the right lower lung field.
た.

現病歴：60歳頃に検診で右胸腔内腫瘤を指摘された が，穿刺にて診断つかず経過観察とされていた，以降ほ とんど通院せず放置していたが，著明な拡大を認めたた め，治療目的に当科紹介となった。

入院時現症：右下肺野で呼吸音が減弱していた，その 他に感染兆候などの所見を認めなかった。

血液検査所見 : 凝固系も含めて異常はなかった.

胸部単純 $\mathbf{X}$ 線所見：右下肺野に境界明瞭な腫瘤陰影 を認めた（Fig. 5).

胸部 CT 所見 : 右胸腔内尾側を占拠する最大径 $16 \mathrm{~cm}$ 大で，内部に石灰化を伴う腫瘤を認めた。同腫瘤により 右下葉は無気肺を呈し, 横隔膜と肝臓が変形していた (Fig. 6).

手術所見：右側方切開により血腫被膜切除および胸膜 外剥離を伴う右肺下葉切除術を施行. 横隔膜は人工物に よる再建を避けて温存した筋層を縫縮して再建した。

術後経過：18 病日に脳梗塞を合併したが, 感染やその 他呼吸器合併症の兆候はなく軽快し術後 1 年経過し独歩 通院中である.

\section{考察}

CEH は臨床経過や組織像が慢性硬膜下血腫と類似す ると指摘されており ${ }^{1)}$, 本邦では胸腔内の報告が最も多 い. 病因としては結核性膿胸や外傷, 胸部手術後の症例 に多く報告されており，現在のところ新生血管の破綻と

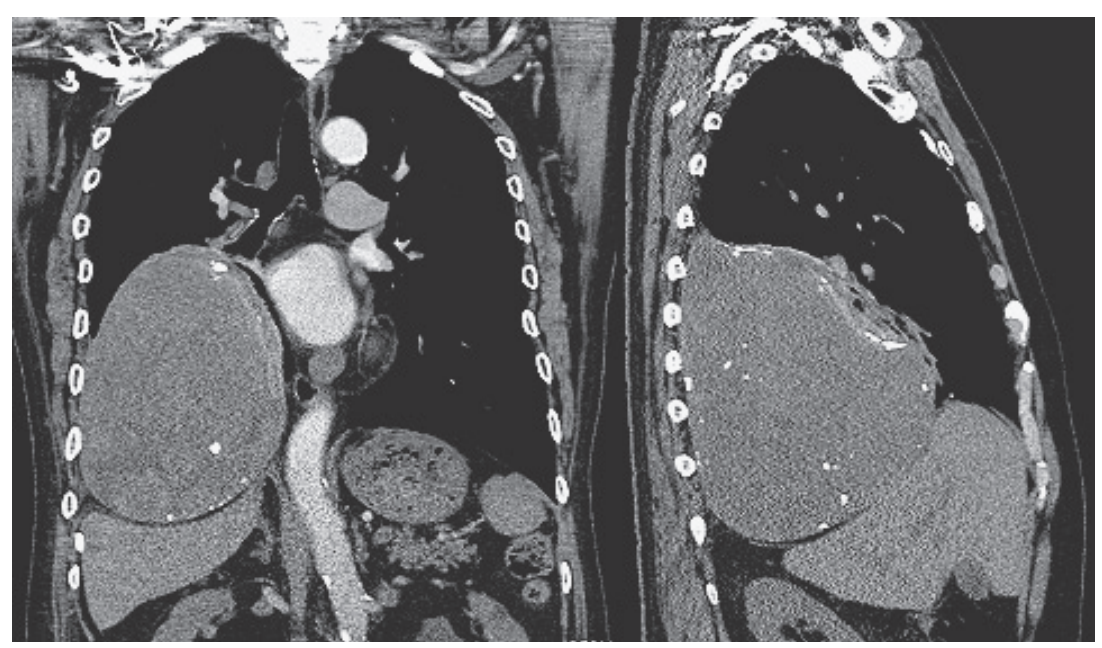

Fig. 6 Chest CT scan showing the mass, $16 \mathrm{~cm}$ in size, with calcification, and the right lower lung lobe atelectasis and liver form change caused by the mass. 
再生を繰り返した結果生じる腫瘤勇と考えられている.鑑 別診断として膿胸関連リンパ腫（PAL）を中心とした悪 性疾患がある. CT では内部に石灰化があり腫瘤の周囲 が被膜に覆われていること, MRI では T2 強調画像で内 部がモザイク状を呈することが $\mathrm{CEH}$ の特徵とされてい るが, 画像所見に加えて既往歴や生検, 腫瘍マーカーな どと組み合わされて総合的に判断される ${ }^{4.5)}$. 臨床症状は 症例により様々であり, 今回の 3 例においても無症状か ら隣接臟器の圧迫症状, 胸腔外伸展による疼痛などを呈 していた. しかし本症は, 放置すれば血腫の拡大進展に より, 確実に何らかの臨床症状を呈すると考えられる5 それゆえ診断後は速やかな治療が望まれるが, 本症には 結核治療後や胸部外科治療後の遠隔期合併症との側面が あり ${ }^{5}$, 今回の 3 例のように高齢患者も散見されるため, 高侵襲な治療介入が躊躇される場合がある. 治療の基本 は血腫除去であるが, 術後に死腔が残りやすく再発およ び感染の制御が肝要である．また血腫被膜を残した手術 による再発の報告があり ${ }^{6}$, 被膜を含めての血腫完全切除 が原則とされている. 当科でも再発と感染の制御のため, 被膜の完全切除を目指すと同時に周囲臓器の可及的な温 存により術後の死腔を小さくし, 人工物の使用も極力避 けることが望ましいと考えている. しかし実際には周囲 との癒着が強固で, 被膜の完全切除には周囲臓器の拡大 合併切除が必要となることが多い ${ }^{5,7.9)}$. 症例 1 では, 全身 状態を鑑みて血腫除去のみを行ったが, 術後間もなく感 染し慢性膿胸化した. 症例 2,3 に関しては近接臓器合併 切除を伴う完全切除を行ったが, 特に死腔の大きい症例 2 において周術期の管理に難渋した. $\mathrm{CEH}$ は病態が慢性 硬膜下血腫と類似する ${ }^{1)}$ とされるが, 慢性硬膜下血腫の治 療では被膜を残した血腫除去とドレナージのみの施行が 一般的であり $10 \%$ 程度の再発融があるとされている. 胸 部 CEH では血腫除去のみの報告が少なく評価が難しい が, 全身状態によっては可及的血腫被膜除去も選択肢と なりうると考えられる.

\section{おわりに}

異なる経過をたどった胸部 CEH の 3 手術例を経験し た. 治療としては被膜の完全切除を伴う血腫除去が最善 であるが, 高侵襲手術となることも多く各症例の全身状 態に応じた治療戦略が望まれる.

\section{文献}

1. Reid JD, Kommareddi S, Lankerani M, Park MC. Chronic expanding hematomas. A clinicopathologic entity. JAMA 1980; 244: 2441-2.

2. 井内敬二, 稲田啓次, 山本元三, 一宮昭彦, 多田弘人, 森 隆，他. 慢性膿胸の特殊型 (基質化膿胸)について。 日呼 外会誌 1988; 2: 11-7.

3. Labadie EL, Glover D. Physiopathogenesis of subdural hematomas. Part 1: Histological and biochemical comparisons of subcutaneous hematoma in rats with subdural hematoma in man. J Neurosurg 1976; 45: 382-92.

4. 黒崎敦子. 胸膜, 胸壁のリンパ腫. 日胸臨 2011; 70: 5609.

5. 斎藤勢也, 仁木俊助, 田中 隆, 川上行奎, 香川典子. 通 過障害を来した胸部 Chronic expanding hematoma の 1 手術例. 日呼外会誌 2012; 26: 197-202.

6. 松毛真一, 細川誉至雄, 山崎左雪, 佐藤一人, 村上洋平, 山川智士, 他. Chronic expanding hematoma に対する 5 手術例の検討. 胸部外科 2000; 53: 768-73.

7. 金 慶一, 高橋秀暢, 伊藤哲思, 小中千守, 加藤治文. Chronic Expanding Hematoma との鑑別が困難であった 結核性膿胸の一例. 日呼外会誌 1999; 13: 649-53.

8. 栄福亮三, 中西良一, 大崎敏弘, 吉野一郎, 吉松 隆, 安 元公正.巨大腫瘤を呈したChronic Expanding Hematoma の 1 例. 日呼外会誌 1998; 12: 146-50.

9. 井内敬二, 田中靖士, 田中寿一, 櫛部圭司, 池田正人, 堀 田隆久, 他. 25 年前の肺葉切除後に生じた慢性出血性膿 胸の 1 治験例. 日胸 1994; 53: 869-74.

10. 長嶋宏明, 坂田純一, 石井大嗣, 千葉義幸, 三宅 茂. 慢 性硬膜下血腫の再発因子についての検討. 脳外誌 2010; 19: 845-9. 


\title{
Three different cases of chronic expanding hematoma of the thorax
}

\author{
Yoshihiro Miyauchi, Hideto Okuwaki, Hirochika Matsubara \\ Hiroyasu Matsuoka, Tsuyoshi Uchida, Masahiko Matsumoto \\ 2nd Department of Surgery, Yamanashi University, Japan
}

We report 3 different cases of chronic expanding hematoma (CEH) of the thorax. Case 1: A 70-year-old man with a history of thoracoabdominal aortic replacement became aware of a painful left chest wall mass. The patient underwent the extirpation of a hematoma. Case 2: A 74-year-old woman with a history of lobectomy for tuberculosis became aware of hemoptysis. The patient underwent a left pneumonectomy. Case 3: An asymptomatic 74-year-old man with a history of tuberculous pleuritis was admitted with an increasing mass in the right thorax. The patient underwent a right lower lobectomy. In the treatment of $\mathrm{CEH}$, a surgical strategy corresponding to each patient's general state is required.

(C) The Japanese Association for Chest Surgery (JACS) 